\title{
The Relationship between Overweight and Obesity and Depressive Disorders among Adolescents: Upper Silesia, Poland
}

\author{
Iwona Lizończyk* and Jadwiga Jośko-Ochojska \\ Chair and Department of Medicine and Environmental Epidemiology, Medical University of Silesia in Katowice, ul. \\ Jordana 19, 41-808 Zabrze, Poland
}

Received: August 02, 2018; Accepted: August 24, 2018; Published: August 31, 2018

*Corresponding author:Iwona Lizończyk, Chair and Department of Medicine and Environmental Epidemiology, Medical University of Silesia in Katowice, ul. Jordana 19, 41-808 Zabrze, Poland , Tel: +48 577067 418; E-mail: ilizonczyk@o2.pl

\begin{abstract}
Background: Overweight and obesity are key health problems in many countries that affect an increasing number of teenagers. Among Polish children and adolescents, the most rapid weight gain, compared to other European countries has been noted. In addition, this excessive body weight usually coexists with depressive disorders. The epidemiological scale of the problem is worrisome.
\end{abstract}

Objectives: Assessment of the prevalence of overweight, obesity and depressive disorders in adolescents, and identifying correlations between these disorders.

Materials and Methods: A group of 1002 high school students was analyzed. Eating habits, regularity of meals and inclination towards snacking were assessed with the author's survey, while depressive disorder was evaluated with The Beck Depression Inventory questionnaire. Data were processed with STATISTICA 12.0.

Results: In the study group of adolescents, $24.7 \%$ suffered from overweight and obesity. Excessive body weight was associated with poor nutritional habits and the problem of excess body mass in the participants' families. In addition, overweight and obesity were more pronounced in boys $(28,5 \%)$ and the type of school also played a role. Depressive disorders were revealed in $43.3 \%$ of the students, in which case girls were more affected (49.9\%). More depressive disorders were reported in overweight and obese students (60.4\%), including $71.1 \%$ of girls. Among adolescents with depressive disorders, $62.8 \%$ reported emotional eating, while excessive body weight exacerbated that problem $(76.4 \%)$. Nearly $62.7 \%$ of the students with depressive disorder showed reduced concentration and learning difficulties. Similarly, up to $70 \%$ of overweight and obese students revealed learning problems.

Conclusions: Rates of overweight and obesity among adolescents are alarming, and nearly half of them suffer from depressive disorders, reduced concentration and learning difficulties. Moreover, excessive body weight exacerbates depressive disorders, concentration and learning difficulties. There is a necessity to provide health education to adolescents, their parents, and teachers at an early stage of the development.

Keywords: overweight; obesity; depressive disorders; adolescents

\section{Introduction}

Overweight and obesity are one of the main health problems faced by many countries around the globe. In 1977, the World Health Organization recognized obesity as a worldwide epidemic and one of the major threats to health and life. According to WHO estimates, 2.3 billion people around the world suffer from overweight and 700 million from obesity. The problem of obesity affects both highly industrialized countries as well as countries with a lower GDP [1]. Although the prevalence of obesity among adults has increased regularly in most countries over the last thirty years, it has been growing faster among teenagers and adolescents, which is a concern [2]. This is an alarming phenomenon since excessive body weight during adolescence is still present in $70 \%$ of persons during adulthood [3]. The latest published data show that about $10 \%$ of the population worldwide up to 18 years of age suffer from overweight or obesity [4], while American studies found that excessive body weight is observed among $30 \%$ of young people [2].Epidemiological data on Poland are especially alarming. According to a European Health Interview Survey from 2014, overweight and obese persons in Poland, respectively, account for $36.6 \%$ and $16.7 \%$ of the overall population aged 15 years and more [5].

The latest report of the Food and Nutrition Institute in Warsaw showed that as many as $28 \%$ of boys and $22 \%$ of girls who attend the last grade of primary school have an excessive body weight [6]. Results of the studies carried out among children and adolescents from Cracow, from 3.5 to 20.5 years of age, are similarly alarming [7].

We have overtaken many Western countries in terms of the prevalence of overweight and obesity in children and adolescents, as shown by an ENERGI study from 2010 and by a UNICEF report $[6,8]$. This analysis shows that Polish children and adolescents are suffering from the most rapid weight gain in Europe and the number of young people with excessive body weight has doubled over the last decade.

Overweight means an excessive content of fat tissue in the body, which exceeds the accepted standards and as a consequence 
leads to a gain in body weight, whereas obesity is a pathological accumulation of fat tissue, which exceeds the physiological needs

of the body and its adaptive capabilities. Body Mass Index (BMI) is used to assess normal body weight. Overweight is defined as a BMI higher than 25 and obesity when the BMI exceeds 30 . Overweight and obesity have serious health consequences. They may cause many somatic problems: low physical strength, musculoskeletal, cardiovascular and gastrointestinal diseases, diabetes type II, endocrine diseases and many other disorders. Overweight and obesity are especially dangerous in adolescence since this condition is often also present in the later period of life, increasing the risk of metabolic diseases [9-11].

Moreover, overweight and obese persons may manifest psychological problems. They are often mocked, insulted and discriminated against, which may contribute to their withdrawal from active life, avoidance of confrontations with adversities, loss of self-confident and low self-esteem. Oversensitivity, increased tension, and anxiety are often observed in persons with excessive body weight. They are also less resistant to stress [12]. Mood swings may be often accompanied by depressive disorders.

There are many relationships between mood swings, depressive disorders, and an increased body weight. Extensive epidemiological studies, which were performed in the previous years, showed a higher risk of mood swings and depressive disorders in obese persons (BMI>30) [13]. This is especially significant during adolescence, which is a period marked by an increased risk of developing eating disorders. Emotional problems, abnormal family relationships, excessive school and parental expectations are compensated by the pleasure of eating.

On the other hand, depressive disorders in youth may be a risk factor for obesity at a later age. Studies on obesity and depressive disorders in adolescents have shown that adverse experience in the childhood and mood swings in adolescents are related to more advanced obesity and increased BMI in adult life. Besides, the more advanced the obesity, the higher their prevalence [14].

An increased level of stress may also be a factor contributing to both depression and obesity. A high level of glucocorticoids, which is observed when under stress, contributes to an increase in appetite, and thus the quantity of eaten food.

Change in body weight, as well as, overeating may significantly affect the frequent occurrence of bad moods [15]. Along with the increasing epidemic of overweight and obesity, their growing impact on the quality of life and the risk of developing chronic diseases has been observed. They may be also risk factors for depressive disorders. Recently, many Polish and foreign studies have been published that were dedicated to the correlations between eating and depressive disorders but referred mainly to adults. There are few reports that explore this relationship in adolescents.

The fact that adolescence is a time marked by an increased risk of developing this type of disorders as well as the progressive growth of excess body weight among children and adolescents in Poland encouraged the authors to carry out their own study related to this problem.

The goal of the research was to assess the prevalence of overweight and obesity as well as depressive disorders among adolescents from the Silesian voivodship and to reveal the correlation between them.

\section{Materials and Methods \\ Study Setting and Participants}

The study was carried out in eight schools in Upper Silesian voivodeship including three high schools, two vocational schools, and three technical schools. The varied type of school was chosen in order to include the similar number of participants of both genders, as well as to ensure the wider scope of the study and allow for consideration of the possible role the type of school might play in the research results.

The study included 1002 students with 487 girls (48.6\%) and 515 boys (51.4\%) in the period from January to June 2014 and from March to June 2016. Participation in the study was voluntary and anonymous. The analysis was focused on adolescents aged from 16 to 18 years who attended high schools in Bytom, Zabrze, and Gliwice (Silesian Voivodeship) and was approved by the Bioethical Commission No KNW/0022/KB/223/14.

\section{Data Collection}

The study was based on a questionnaire which consisted of two types of surveys which were to be filled in by the respondents on their own.

The first part included the authors' survey which had previously been validated. It included a section dedicated to the respondent's personal data (gender, body weight, height, age) from which BMI was calculated and 50 questions related to eating habits, regularity of meals, snacking, physical activity and evaluation of fatigue and concentration disorders.

The Beck Depression Inventory, BDI, made up the second part of the questionnaire. This is a self-evaluation scale used to measure the severity of depression based on 21 questions, which referred to the last month before the study. Each question has four possible answers that indicate any increased intensity of symptoms and are scored from 0 to 63 .

\section{Data Processing and Analysis}

By using body weight and height, BMI was calculated (body weight in $\mathrm{kg}$ and the square height in $\mathrm{m}$ ) and the respondents were qualified in the following way:

BMI $<18.5$ - underweight

BMI 18.5 - 24.9 - normal body weight

BMI 25 - 29.9 - overweight

BMI > 30 - obesity

Since these BMI values were originally defined for adults, in 
case of children and adolescents (up to 18 years of age), percentile norms including current height and body weight standards as well as BMI are applied. At present, percentile norms, which were developed as part of the OLAF project, are used and they were applied in the study:

$\mathrm{BMI}<5$ percentile - underweight

$\mathrm{BMI} \geq 5$ percentile and $<85$ percentile - normal body weight

BMI $\geq 85$ percentile and $<95$ percentile - overweight

$\mathrm{BMI} \geq 95$ percentile - obesity

In the case of Beck Depression Inventory (BDI), lack of depression or the extent of depression are evaluated according to the following score key:

0 -9 - no depression

10-19 - mild depression

20-25 - moderate depression

Above 26 - severe depression

The correlation between the BMI group of obese and overweight adolescents and occurrence of depressive disorders (including the BDI scores) was studied, with the extension of studying other variables, which may have had an impact on the results of the study.

\section{Statistical Analysis}

The obtained figures, after feeding them into a database and the performance of an accuracy test, were submitted to statistical analysis using Statistica 12.0.A descriptive statistics was preliminarily calculated for the studied groups (size of groups, percentage fractions for quantitative variables, the mean for qualitative variables, standard deviation).

The obtained results were presented in the form of tables and diagrams. Intergroup comparisons were performed for quantitative variables with test $t$, and in the case of failure to meet assumptions, the non-parametric Mann Whitney U test was applied.

For qualitative variables, the Chi-squared test with proper corrections dependent on the group size was used. Value $<0.05$ was considered as significant in all the analyses.

\section{Results}

Overweight and obesity were reported in 240 persons who accounted for $24.7 \%$ of all the respondents. In that group, obesity was found in 136 persons (14\%), while 104 persons were obese (10.7\%). The group was compared to a control group of persons with normal body weight. This included 734 persons $(75 \%)$. Underweight people - 28 subjects $(2.8 \%)$ were excluded from the study.

It was shown that overweight and obesity were associated with gender. Body mass index for boys was statistically ( $p=0.0011$ ) higher than BMI for girls. Overweight and obesity was found in
$28.5 \%$ of the boys and $20.7 \%$ of the girls. A marked difference is visible in the case of obesity which affected $17.8 \%$ of the boys and $9.8 \%$ of the girls. Normal body weight was reported in $71.5 \%$ of the boys and $79.3 \%$ of the girls (Figure 1).

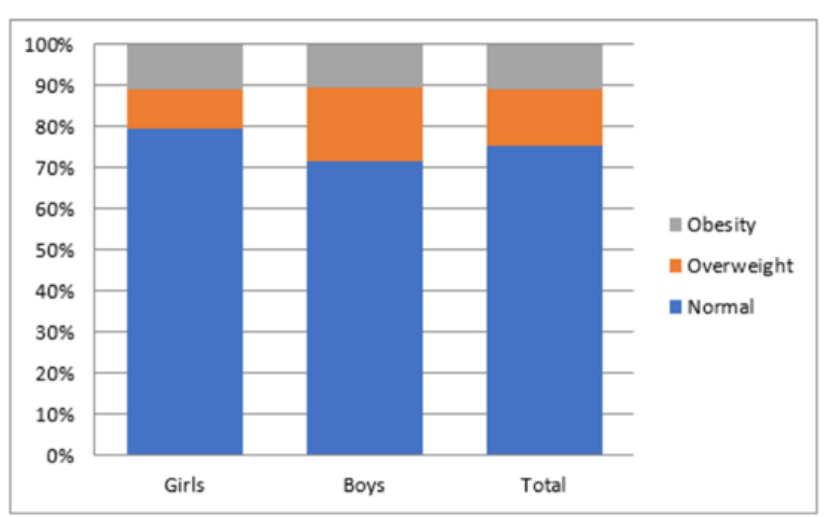

Figure 1: BMI classes and gender

The study showed a statistically significant $(\mathrm{p}=0.0292)$ relationship between BMI and the type of school. The highest number of students with abnormal body weight was found in technical schools and they accounted for $27.8 \%$ (17.2\% of overweight persons, $13.9 \%$

of obese persons); this number was $26.7 \%$ (17.2\% of overweight persons, $9.5 \%$ of obese persons) in vocational schools and $19.8 \%$ in high schools (11.4\% of overweight persons, $8.4 \%$ of obese persons).

Body weight was affected to a great extent by the regular consumption of meals during the day-in particular, the regular consumption of breakfast. More people eating breakfast manifested a normal body weight $(65.3 \%)$ when compared to non-breakfast eaters (34.7\%) and this was statistically significant $(\mathrm{p}=0.0199)$.

A statistically significant relationship $(p=0.0000)$ between regular breakfast eating and type of school was revealed. The highest number of breakfast eaters was in the high schools $(72.8 \%)$ where the highest number of people with normal body weight was also found.

It was noticed that there was a statistically significant $(\mathrm{p}=0.0000)$ relationship between adolescents developing overweight and obesity and the abnormal body weight of family members. As many as $77.3 \%$ of persons who reported such a problem in their families, suffered from excessive body weight. That group included $40.2 \%$ of overweight people and $37.1 \%$ of obese people.

It was shown that $43.3 \%$ of the surveyed adolescents $(422$ persons) manifested depressive disorders which in $29.9 \%(291$ persons) were mild, in 6\% (59 persons) moderate and 7.4\% (72 persons) severe. 
Figure 2 shows the statistically significant $(\mathrm{p}=0.0002)$ relationship between depressive disorders and gender. Girls accounted for $49.9 \%$ of the group of persons who reported depressive disorders and boys accounted for $37.2 \%$. Differences between girls and boys were present in all the Beck categories.

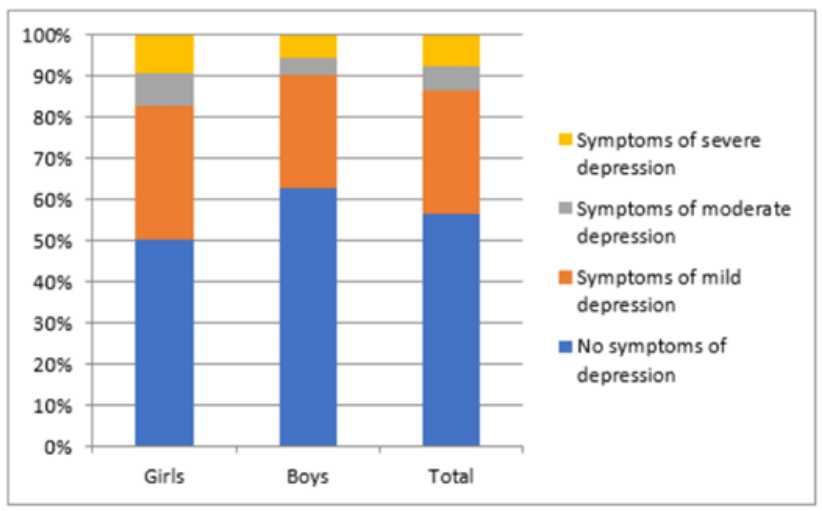

There is a relationship between The Beck Depression Inventory and the prevalence of overweight and obesity in adolescents. There were more persons with depressive disorders $(60.4 \%)$ in the group of overweight and obese people (the study group) than in the group of people with normal body weight (the control group), where they accounted for $37.7 \%$.

Gender was a statistically significant $(\mathrm{p}=0.0256)$ factor in the concurrence of depressive disorders and overweight or obesity in adolescents. There were $71.1 \%$ if girls and $53.2 \%$ of boys in the group of overweight and obese persons. Differences between girls and boys were visible in all classes of depressive disordersmild, moderate and severe. A clear difference between girls and boys was especially observable in the aspect of severe depressive disorders. Such symptoms were reported by twice as many girls (13.4\%) as boys (6.3\%) (Table 1$)$.

No statistically significant $(\mathrm{p}=0.0825)$ relationship was found between the severity of depressive disorders and type of school attended by the adolescents.

Figure 2: Depressive disorders and gender

Table1: Depressive disorders and gender in study and control group

\begin{tabular}{|c|c|c|c|c|c|}
\hline \multirow{3}{*}{ Gender } & \multicolumn{5}{|c|}{ Depressive Disorder } \\
\hline & No & Mild & Moderate & Severe & \multirow[b]{2}{*}{ In Total } \\
\hline & (Quantity/\%) & (Quantity/\%) & (Quantity / \%) & (Quantity/\%) & \\
\hline \multicolumn{6}{|c|}{ Study Group } \\
\hline Girls & $28.90 \%$ & $47.40 \%$ & $10.30 \%$ & $13.40 \%$ & 97 \\
\hline Boys & $46.80 \%$ & $39.20 \%$ & $7.70 \%$ & $6.30 \%$ & 143 \\
\hline In Total & 94 & 103 & 21 & 22 & 240 \\
\hline \multicolumn{6}{|c|}{ Control Group } \\
\hline Girls & $55.60 \%$ & $28.80 \%$ & $7.30 \%$ & $8.30 \%$ & 372 \\
\hline Boys & $69.10 \%$ & $22.60 \%$ & $3 \%$ & $5.30 \%$ & 362 \\
\hline In Total & 458 & 188 & 38 & 50 & 734 \\
\hline
\end{tabular}

A statistically significant $(\mathrm{p}=0.0000)$ correlation was found between depressive disorders and comfort eating. The problem of consuming food when concerned or troubled affected $62.8 \%$ of those with depressive disorders and $37.2 \%$ of those without them.

In the case of overweight and obese people (the study group), there is even a stronger and statistically significant $(\mathrm{p}=0.0000)$ need to alleviate stress with additional servings of food $(76.4 \%)$ when compared to the control group (55\%) (Table 2).

It was shown that $36.3 \%$ of the surveyed adolescents reported the reduced concentration and learning difficulties.
That problem was present in $62.7 \%$ of those $(\mathrm{p}=0.0000)$ with depressive disorders. Overweight and obesity among adolescents contributed to the concurrence of depressive disorders, reduced concentration and learning difficulties. As many as $70 \%$ of subjects with excessive body weight (the study group) also manifested depressive disorders, reduced concentration and learning difficulties ( $\mathrm{p}=0.0135)$. This was observed in $60.2 \%$ of adolescents with normal body weight $(\mathrm{p}=0.0000)$. These results are presented in Table 3. 
Table 2: Depressive disorders and reaching out for additional servings of food in study and control group

\begin{tabular}{|c|c|c|c|c|c|}
\hline \multirow[b]{2}{*}{$\begin{array}{l}\text { Alleviation Of Stress With } \\
\text { Food }\end{array}$} & \multicolumn{5}{|c|}{ Depressive Disorders } \\
\hline & $\begin{array}{c}\text { No } \\
\text { (Quantity/\%) }\end{array}$ & $\begin{array}{c}\text { Mild } \\
\text { (Quantity/\%) }\end{array}$ & $\begin{array}{c}\text { Moderate } \\
\text { (Quantity / \%) }\end{array}$ & $\begin{array}{c}\text { Severe } \\
\text { (Quantity/\%) }\end{array}$ & In Total \\
\hline \multicolumn{6}{|c|}{ Study Group } \\
\hline No & $56.40 \%$ & $32.50 \%$ & $5.10 \%$ & $6 \%$ & 116 \\
\hline Yes & $23.60 \%$ & $52.00 \%$ & $12.20 \%$ & $12.20 \%$ & 124 \\
\hline In Total & 94 & 103 & 21 & 22 & 240 \\
\hline \multicolumn{6}{|c|}{ Control Group } \\
\hline No & $69.60 \%$ & $23 \%$ & $3.50 \%$ & $3.90 \%$ & 516 \\
\hline Yes & $45 \%$ & $32.10 \%$ & $9.20 \%$ & $13.70 \%$ & 218 \\
\hline In Total & 458 & 188 & 38 & 50 & 734 \\
\hline
\end{tabular}

Table 3: Depressive disorders as well as reduced concentration and learning difficulties in study and control group

\begin{tabular}{|c|c|c|c|c|c|}
\hline \multirow{2}{*}{$\begin{array}{l}\text { Reduced Concentration and } \\
\text { Learning Difficulties }\end{array}$} & \multicolumn{5}{|c|}{ Depressive Disorders } \\
\hline & $\begin{array}{c}\text { No } \\
\text { (Quantity/\%) }\end{array}$ & $\begin{array}{c}\text { Mild } \\
\text { (Quantity/\%) }\end{array}$ & $\begin{array}{c}\text { Moderate } \\
\text { (Quantity/\%) }\end{array}$ & $\begin{array}{c}\text { Severe } \\
\text { (Quantity/\%) }\end{array}$ & In Total \\
\hline \multicolumn{6}{|c|}{ Study Group } \\
\hline No & $45.40 \%$ & $42.00 \%$ & $7.30 \%$ & $5.30 \%$ & 150 \\
\hline Yes & $30 \%$ & $43.30 \%$ & $11.10 \%$ & $15.60 \%$ & 90 \\
\hline In Total & 94 & 103 & 21 & 22 & 240 \\
\hline \multicolumn{6}{|c|}{ Control Group } \\
\hline No & $75 \%$ & $19.70 \%$ & $2.30 \%$ & $3 \%$ & 470 \\
\hline Yes & $39.80 \%$ & $36.40 \%$ & $10.20 \%$ & $13.60 \%$ & 264 \\
\hline In Total & 458 & 188 & 38 & 50 & 734 \\
\hline
\end{tabular}

\section{Discussion}

Based on the analysis of the collected material, it was found that the problem of excess body weight affects $24.7 \%$ of adolescents, aged from 16 to 18 years, from Silesian schools. These results are consistent with the latest reports from WHO [1], the results of the European Health Interview Survey (EHIS) from 2014 and the studies of the Food and Nutrition Institute in Warsaw [5]. In terms of Poland, these figures are higher than the national average $(22.3 \%)$ and lower than in the Mazowieckie (32\%) or Lodzkie (29.8\%) voivodeship [6].

There are many studies which confirm the relationship between abnormal body weight and gender. In Krzyżaniak's studies, the proportion of overweight students was $21 \%$ for boys and $15 \%$ for girls and obesity was diagnosed in $5.1 \%$ of boys and $3.7 \%$ of girls. Furthermore, the results of the Health Behaviour in School-aged Children (HBSC) study which was conducted in the 2013/2014 school year, confirmed that overweight and obesity are developing decidedly more frequently among Polish boys and girls (respectively $19.2 \%$ and $10.4 \%$ ). This is confirmed by the author's study which showed abnormal body weight in $28.5 \%$ of boys and $20.7 \%$ of girls $[16,17]$.
Shaping good eating habits among adolescents is affected by many different factors, although family and school have the greatest impact. According to various scientific reports, the family home is one of the most important sources of knowledge on nutrition $[18,19]$. There is a relationship between overweight and obesity among adolescents and the abnormal body weight of family members, as demonstrated by the author's own study. It turned out that $77.3 \%$ of adolescents with excessive body weight reported this problem in their family.

The author's own research showed a correlation between abnormal body weight and the type of school attended by the adolescents. The highest number of people with abnormal body weight attended technical schools (27.8\%), with $26.7 \%$ attending vocational schools, and $19.8 \%$ in the secondary schools. On the one hand, this resulted from the higher number

of boys (with a higher proportion of overweight and obesity) in technical and vocational schools and a majority of girls (with a higher proportion of normal body weight) in the secondary schools.

On the other hand, when analyzing boys and girls with excessive body weight in individual types of schools, it was noticed that 
the number of overweight and obese boys is lower in secondary schools $(22.3 \%)$ than in vocational schools (33.8\%) and technical schools $(26.7 \%)$. Given the above, it can be concluded that in the secondary schools, there is higher awareness of eating habits and choices. Due to the lack of literature data on this relationship, a detailed analysis of the effect of the school environment on nutritional education as well as lifestyle should be a subject of subsequent studies.

Insufficient knowledge of students on the regularity of meals, including eating breakfast, proved to be a contributory factor to excessive body weight. The relationship between the regular consumption of breakfast and body weight was examined in the author's own group. Normal body weight was reported in $65.3 \%$ of those who eat breakfast whereas this figure was $34.7 \%$ among non-breakfast eaters. Besides, it turned out that the highest number of breakfast eaters attend secondary schools (72.8\%), where the proportion of overweight and obese people was the lowest. This relationship was confirmed by the Król et al. studies which were performed among a group of adolescents living in a Silesian agglomeration [20].

In the study group, a higher number of students of secondary and technical schools eat breakfast when compared to vocational schools. Ilow also writes about the role of regular meals, including breakfast [21].

Scientific reports show that $70-80 \%$ of obese adolescents will become obese adults with a high risk of complications including ischaemic heart disease, arterial hypertension, type 2 diabetes, gastrointestinal diseases, endocrine disorders and many other health problems [9-11].

When discussing the consequences of obesity, psychological outcomes such as depressive disorder, non-acceptance of one's own appearance and lower social evaluation cannot be overlooked. Adolescence is a time marked by an increased risk of developing such disorders. Dymowski and Nowicka-Sauer studies showed that $25.7 \%$ of high school students suffer from depressive disorders [12,32]. The author's own study revealed depressive disorders in $43.3 \%$ of the surveyed adolescents (mild$29.9 \%$, moderate $-6 \%$, severe $-7.4 \%$ ).

There are many studies on the relationship between obesity and mood swings, anxiety and depressive disorders. The first survey study was conducted by Simon, et al. Other studies by Mooreville Shomaker, et al. as well as Marmorstein NR, et al. show that early depressive disorders in adolescents are associated with a subsequent risk of obesity and vice versa-obesity in the early youth is related to the increased probability of subsequent depressive disorders [22-24]. The author's own research showed that there are significantly more people with depressive disorders $(60.4 \%)$ among overweight and obese adolescents than among those with a normal body weight (37.7\%).

Gender plays a significant role in the case of concurrence of depressive disorders as well as overweight and obesity in adolescents. This relationship is described by Łuszczyńska and Bąk-Sosnowska $[15,25]$. In the author's own study on a group of persons with abnormal body weight, depressive disorders were reported by $71.1 \%$ of girls and $53.2 \%$ of boys. There may be various reasons behind these disproportions. In the case of girls, it might result from the greater environmental and media pressure related to appearance and their own exaggerated expectations. In the case of boys, cultural patterns, which sometimes prevent them from admitting to weakness and depression, as well as attaching too much importance to their appearance, may play an important role.

Many publications, both foreign: Pasold et al. Kaufer et al. Mc Elroy et al. and Polish: Sikorska, Wiśniewska and Dudek, Jaeschke have underlined the relationship between depressive disorders and comfort eating [26-30].

This was also shown in the author's own study where the problem of reaching for food when feeling stressed affected those from all classes of depressive disorders (mild, moderate and severe). It was additionally shown that this problem was even more intense among overweight and obese adolescents.

Furthermore, the author's own study showed that adolescents with depressive disorders have reduced concentration and learning difficulties. This problem affects $62.7 \%$ of students. It turned out that overweight and obesity contribute to the concurrence of depressive disorders, reduced concentration and learning difficulties. Nearly $70 \%$ of the respondents with abnormal body weight showed depressive disorders and concentration problems as well as learning difficulties. A similar correlation was observed in a prospective study performed by KorczakLimpan among a group of 3294 subjects [31].

\section{Conclusions}

To sum up, the problem of overweight and obesity in adolescents is an alarming phenomenon, since it affects almost $1 / 4$ of high school students, mainly boys. Abnormal body weight is caused, in the first place, by poor eating habits and excessive body weight in family members. More than half of adolescents suffer from depressive disorders, reduced concentration and learning difficulties. There is a correlation between overweight and obesity, and the development of depressive disorders, reduced concentration and learning disabilities among adolescents. Scientific reports show that an excessive body weight may be both the cause and the consequence of depressive disorders in adolescents. Furthermore, the study results have shown that the excessive body weight exacerbated depressive disorders, which was particularly evident among girls.

These findings also reinforced the tendency towards comfort eating and contribution to a deterioration of concentration and learning difficulties, which accompany depression. Finally, it is crucial to provide an effective health education for prevention of obesity to adolescents, their parents, and teachers, at an early stage of the development. 


\section{Declarations}

Conflicts of interest: NA

Ethical approval: Approved by the Bioethical Commission No KNW/0022/KB/223/14.

Clinical trial registration: NA

\section{References}

1. Galal OM, Hulett J. Obesity among schoolchildren in developing countries. Food Nutr.Bull. 2005;26(Suppl 2):261-266. DOI: $10.1177 / 15648265050262 \mathrm{~S} 217$

2. Hedley AA, Ogden CL, Johnson C, Carroll MD, Curtin LR, Flegal KM. Prevalence of overweight and obesity among US children, adolescents, and adults. JAMA. 2004;291(23):2847-2850. DOI: 10.1001/ jama.291.23.2847

3. Margarey AM, Daniels LA, Boulton TJ, Cockington RA. Predicting obesity in early adulthood from childhood and parental obesity. Int J ObesRelatMetabDisord. 2003;27(4):505-513. DOI: 10.1038/ sj.ijo.0802251

4. Haslam DW, James WP. Obesity. Lancet. 2005;366(9492):1197-1209. DOI: 10.1016/S0140-6736(05)67483-1

5. Stan zdrowia ludności Polski w 2014 r [in Polish]. Warsaw: GUS; 2016.

6. Wojtasiński Z. Raport Iżiż. Co czwarty uczeń szkoły podstawowej ma nadwagę i jest otyły [in Polish]. PAP. October 10, 2013.

7. Chrzanowska M, Gołąb S, Żarów R. Trendy w otłuszczeniu ciała oraz występowanie nadwagi i otyłości u dzieci i młodzieży Krakowa w ostatnim trzydziestoleciu [in Polish]. Pediatr Pol. 2002;77:113-119.

8. Sowa B. Raport Unicef: Polskie dzieci tyją najszybciej w Europie [in Polish]. April 162013.

9. Kaur H, Hyder ML, Poston WS. Childhood overweight an expanding problem. TreatEndocrinol. 2003;2(6):375-388.

10. Adair LS, Gordon-Larsen P. Maturational timing and overweight prevalence in US adolescent girls. Am J Public Health. 2001;91(4):642644.

11.In-Iw S, Biro FM. Adolescent women and obesity. J PediatrAdolesc Gynecol. 2011;24(2):58-61. doi: 10.1016/j.jpag.2010.08.017

12.Jarosz M, Kłosiewicz-Latoszek L.Otyłość-zapobieganie i leczenie. Warsaw: Wydawnictwo Lekarskie PZWL; 2006.

13. McIntyre RS, Konarski JZ, Wilkins K, Soczynska JK, Kennedy SH. Obesity in bipolar disorder and major depressive disorder: results from a national community health survey on mental health and well-being. Can J Psychiatry. 2006;51(15):274-280. DOI: $10.1177 / 070674370605100502$

14. Stunkard AJ, Faith MS, Allison KC. Depression and obesity. Biol Psychiatry. 2003;54(3):330-337. Doi: 10.1016/S00063223(03)00608-5
15.Łuszczyńska A.Nadwaga i otyłość. Interwencje psychologiczne [in Polish]. Warsaw: Wydawnictwo Naukowe PWN; 2007.

16. Krzyżaniak A. Zdrowie poznańskich uczniów[in Polish]. Poznan: Wydawnictwo Miejskie; 2009.

17. Mazur J.Health and health behaviors of school children in Poland against the background of selected sociodemographic conditions, results of the HBSC 2014 study [in Polish] .Warsaw: Institute of Mother and Child; 2015. 2011;92(4):816-819.

18. Heszen-Niejodek I, Sęk H.Psychologia zdrowia[in Polish]. Warsaw: Wydawnictwo Naukowe PWN; 1997:21-110.

19. Król H, Jankowska M, Hombek E, Biskup M.Dobrostan a rozwój i zdrowie dzieci i młodzieży[in Polish].Lublin: Wydawnictwo Naukowe Neurocentrum; 2016.

20. Ilow R. Assessment of nutritional habits of the students of Medical Academy in Wroclaw. Adv Clin Exp Med. 2005;14,5:929-938.

21. Simon GE, Von Korff M., Saunders K, Miglioretti DL, Crane PK, van Belle G, et al. Association between obesity and psychiatric disorders in the US adult population. Arch Gen Psychiatry. 2006;63(7):824-830. DOI: 10.1001/archpsyc.63.7.824

22. Mooreville M, Shomaker LB, Reina SA, Hannallah LM, Adelyn Cohen $\mathrm{L}$, Courville $\mathrm{AB}$, et al. Depressive symptoms and observed eating in youth. Appetite. 2014;75:141-149. doi: 10.1016/j.appet.2013.12.024

23. Marmorstein NR, Iacono WG, Legrand L. Obesity and depression in adolescence and beyond: reciprocal risks. Int J Obes (Lond). 2014;38(7):906-911. doi: 10.1038/ijo.2014.19

24. Bąk-Sosnowska M. Psychologia otyłości [in Polish]. Psychiatria.pl.

25. Pasold TL, McCracken A, Ward-Begnoche WL. Binge eating in obese adolescents: Emotional and behavioral characteristics and impact on health-related quality of life. Clin Child Psychol Psychiatry. 2013;19(2):299-312. doi: 10.1177/1359104513488605

26. Kaufer D, Ogle WO, Pincus ZS, Clark KL, Nicholas AC, Dinkel KM, et al. Restructuring the neuronal stress response with anti-glucocorticoid gene delivery. Nat Neurosci. 2004;7(9):947-953. DOI: 10.1038/ nn1296

27. McElroy SL, Kotwal R, Malhotra S, Nelson EB, Keck PE, Nemeroff CB. Are mood disorders and obesity related? A review for the mental health professional. J Clin Psychiatry. 2004;65(5):634-651.

28.Sikorska-Wiśniewska G. Nadwaga i otyłość u dzieci i młodzieży [in Polish]. ŻywnŃaukaTechnol Jakość. 2007;6:71-80.

29. Dudek D, Jaeschke R. Otyłość a depresja [in Polish]. In: Podolec P, ed. Podręcznik Polskiego Forum Profilaktyki. Vol. 2. Kraków: Medycyna Praktyczna; 2010.

30. Korczak DJ, Lipman E, Morrison K, Duku E, Szatmari P. Child and adolescent psychopathology predicts increased adult body mass index: results from a prospective community sample. J Dev BehavPediatr. 2014;35(2):108-117. doi: 10.1097/DBP.0000000000000015

31. Dymowska A, Nowicka-Sauer K. Depresja wśród młodzieży-problem wciąż aktualny [in Polish]. Forum Med Rodz. 2015;9(4):124-126. 